\title{
ANALISIS KINERJA DAS PEDINDANG PASCA TAMBANG TIMAH KABUPATEN BANGKA TENGAH, PROVINSI BANGKA BELITUNG
}

\section{Analysis of Pedindang Bassin Performance Post Tin Minning in Central Bangka Regency, Bangka Belitung Province}

\section{Hendi Hendra Bayu ${ }^{1 *}$, Dwi Putro Tejo Baskoro') dan Latief Mahir Rachman ${ }^{2)}$}

\author{
1) Program Studi Ilmu Pengelolaan DAS Sekolah Pascasarjana IPB University, Kampus IPB Darmaga \\ 2) Departemen Ilmu Tanah dan Sumberdaya Lahan, Fakultas Pertanian IPB University, J1. Meranti Kampus IPB \\ Darmaga Bogor 16680
}

\begin{abstract}
Human activities directly affect the physical condition of the land, water quality, and performance of Pedindang Basin. Mining activity is contributing to land damage, decreasing water quality and increasing surface flow. The objectives of this study were: i) analyze the quality of water in the upstream of Pedindang Basin; ii) analyze the level of soil degradation due to the tin mining; and iii) evaluate the Flow Regime Coefficient and Annual Flow Coefficient. This study used GIS analysis. The results of the evaluation showed that the condition of water quality in Pedindang Basin has decreased in the downstream area due to mining activities.
\end{abstract}

Keywords: Coefficients, degradation, evaluation, surface flow

\section{ABSTRAK}

Aktifitas kegitan manusia di dalam DAS Pedindang secara langsung mempengaruhi keadaan fisik lahan, kualitas air, dan kinerja DAS Pedindang. Aktifitas kegiatan penambangan merupakan salah satu faktor yang mengakibatkan kerusakan tanah, menurunnya kualitas air dan meningkatnya aliran permukaan. Tujuan penelitian ini adalah: i) menganalisis kualitas air di DAS Pedindang pada daerah hulu dan daerah lain yang mengalami pencemaran; ii) menganalisis tingkat kerusakan tanah yang berada di DAS Pedindang pasca penambangan timah; iii) mengevaluasi kinerja DAS Pedindang dengan pendekatan Koefisien Regim Aliran (KRA) dan Koefisien Aliran Tahunan (KAT). Penelitian ini menggunakan metode analisis tumpangtindih GIS serta penilaian ambang batas kerusakan tanah, penilaian ambang batas kualitas air dan kinerja DAS dengan penilaian KRA dan KAT. Hasil evaluasi DAS Pedindang menunjukkan bahwa kondisi kualitas air di DAS Pedindang mengalami penurunan di wilayah hilir akibat aktifitas tambang, sehingga perlu adanya penanganan tanah tambang.

Kata kunci: Koefisien, degradasi, evaluasi, aliran permukaan,

\section{PENDAHULUAN}

Kondisi lingkungan DAS di Provinsi Bangka Belitung saat ini menurun. Kerusakan yang terjadi umumnya berkaitan dengan permasalahan pembukaan lahan baru untuk perkebunan, tambang dan pembangunan yang tidak memperhatikan daya dukung lahan. Berdasarkan analisis data tingkat kekritisan lahan di Provinsi Kepulauan Bangka Belitung, luas area lahan kritis mencapai $14,4231.2$ ha $(9 \%)$ dan lahan sangat kritis $117,860.85$ ha $(7 \%)$ dari $1,621,048.4$ ha lahan Provinsi Bangka Belitung (Dinas Lingkungan Hidup Provinsi Bangka Belitung, 2014). DAS Pedindang merupakan salah satu DAS Prioritas di Provinsi Bangka Belitung. Kondisi DAS Pedindang sangat mengkhawatirkan, luas areal DAS Pedindang yang rusak akibat aktivitas manusia mencapai 2,907.4 ha dari 4,6621.8 ha, berdasarkan analisis data Balai Pengelolaan Daerah Aliran Sungai dan Hutan Lindung Provinsi Bangka Belitung (BPDASHL, 2016).

Pembukaan hutan di Pulau Bangka akibat tekanan penduduk, menyebabkan terjadinya konversi lahan. Peningkatan konversi lahan meningkatkan potensi penurunan kapasitas infiltrasi dan peningkatan aliran permukaan pada musim hujan sehingga terjadi pengikisan tanah dan peningkatan erosi.

Konversi lahan di Pulau Bangka didominasi oleh perubahan hutan menjadi lahan tambang, pertanian, dan lahan terbangun (Cerucuk, 2012). Perubahan penggunaan lahan dari hutan utamanya lahan tambang mengakibatkan rusaknya sifak fisik tanah di dalam DAS Pedindang. Dampak negatif penambangan adalah menyusutnya vegetasi di sekitar sungai, meningkatnya sedimentasi, menurunnya derajat kecerahan dan meningkatkan pendangkalan sungai. Tekstur tanah pada lahan pasca tambang didominasi oleh pasir, lebih khusus lagi tanah tersebut mempunyai sifat mudah meloloskan air, kandungan bahan organik rendah serta suhu tanah yang tinggi, sehingga keadaan demikian tidak menguntungkan bagi pertumbuhan tanaman

Besarnya peningkatan aliran permukaan dan sedimentasi DAS Pedindang akan mempengaruhi KAT dan KRA di DAS Pedindang, sehingga mempengaruhi kinerja dari DAS Pedindang. Menurut data DLH Provinsi Bangka Belitung (2016), kondisi kualitas air sungai yang berada di Bangka dikategorikan masuk ke dalam Baku Mutu Air Kelas II. Oleh karena itu penelitian terkait 
evaluasi kondisi DAS pasca tambang sangat diperlukan agar proses penanganan dan perbaikan dapat dilakukan dengan efisien.

Tujuan dari penelitian ini adalah: i) Menganalisis kualitas air di DAS Pedindang pada daerah hulu dan daerah yang mengalami pencemaran, ii) Menganalisis tingkat kerusakan tanah yang berada di DAS Pedindang pasca penambangan timah, iii) Mengevaluasi kinerja DAS Pedindang dengan indikator Koefisien Aliran Tahunan (KAT) dan Koefisien Regim Aliran (KRA).

\section{BAHAN DAN METODE}

\section{Tempat dan Waktu Penelitian}

Penelitian ini akan dilaksanakan pada bulan Januari 2017 sampai Oktober 2017 di DAS Pedindang. DAS Pedindang berada di Kota Pangkalpinang dan Kabupaten Bangka Tengah dengan letak astronomis $106^{\circ} 01^{\prime} 49^{\prime \prime}$ $106^{\circ} 08^{\prime} 41^{\prime \prime}$ BT dan $2^{\circ} 05^{\prime} 40^{\prime \prime}-2^{\circ} 14^{\prime} 13^{\prime \prime}$ LS. Posisi DAS Pedindang berada berdampingan dengan DAS Rangkui dan DAS Pusuk.

\section{Alat dan Bahan}

Peralatan penelitian yang digunakan terdiri dari seperangkat komputer dengan software ArcGIS 10.1 dan Microsoft Office, GPS (Geografic Positioning System), ring sampler, cool box, $\mathrm{pH}$ meter, thermometer, botol sampler dan alat tulis. Data yang digunakan dalam penelitian ini terdiri dari data primer dan sekunder. Data sekunder berupa data spasial peta (tematik) yang didapatkan dari BPDAS HL Provinsi Bangka Belitung dan data non spasial berupa data tabular curah hujan yang bersumber dari BMKG Klas I Depati Amir, data Tinggi Muka Air dari SDA Bangka Belitung, serta laporan hasil penelitian, laporan statistik, amdal, dan lain-lain yang diperoleh dari studi kepustakaan. Data primer diperoleh melalui survey lapang dengan pengambilan titik sampel penelitian secara acak di beberapa titik observasi di daerah DAS Pedindang.

\section{Kerusakan DAS Pedindang}

\section{Analisis Kualitas Tanah}

Pengambilan sampel tanah di lapangan dilakukan dengan menentukkan 19 titik sampel yang di-overlay dari peta tanah, peta penggunaan lahan dan klasifikasi kemiringan lereng. Setelah didapatkan posisi letak sampel dilakukan pengambilan sampel dengan ring sampel. Sampel tanah yang diambil dari lapang kemudian diuji di laboratorium dan hasilnya dinilai dengan parameter indikator ambang kritis tanah, yang mengacu pada Peraturan Pemerintah No 150 tahun 2000 dan keadaaan alami hutan DAS Pedindang, yang ditampilkan pada Tabel 1 .

\section{Analisis Kualitas Air}

Pengambilan sampel air ini dilakukan dengan menentukan titik sampling yang berada di hulu dan di hilir sungai untuk membandingkan kualitas air di DAS Pedindang Pengukuran kualitas air yang dilakukan di lapangan terdiri dari (parameter fisika berupa suhu, $\mathrm{pH}$ serta kimia: $\mathrm{DO}, \mathrm{CO}_{2}$ dan $\mathrm{PB}$. Proses analisis air mengacu pada standar PP Baku Mutu Air No. 82 tahun 2001 yang disajikan disajikan pada Tabel 2.

\section{Koefisien Regim Aliran (KRA)}

KRA merupakan perbandingan debit air tertinggi dengan debit air terendah dalam satu priode (biasanya pada saat musim hujan tertinggi dan musim kemarau). Cara perhitungan Koefisien Regim Aliran dapat dihitung dengan rumus sebagai berikut: $\mathrm{KRA}=\mathrm{Q}_{\max } / \mathrm{Q}_{\mathrm{a}}$; Dimana Koefisien Regim Aliran Qmax (debit maksimum [mm $\left.\operatorname{detik}^{-1}\right]$ ) dibagi dengan Qmin (debit minimum [mm detik ${ }^{1}$ ]). Kemudian diklasifikasikan berdasarkan kelas yang ditampilkan pada Tabel 3.

Tabel 1. Indikator ambang batas kritis tanah berdasarkan PP No 150 tahun 2000 dan keadaan tanah alami di hutan

\begin{tabular}{llccc}
\hline No & \multicolumn{1}{c}{ Parameter } & Satuan & $\begin{array}{c}\text { Ambang Kritis } \\
(\text { PP 150/2000) }\end{array}$ & Tanah Hutan \\
\hline 1 & Fraksi Pasir & $\%$ & $>80$ pasir kuarsitik & $3.34-76.07$ \\
2 & Berat Isi & $\mathrm{g} \mathrm{cm}^{-3}$ & $>1.4$ & $1.13-1.37$ \\
3 & Porositas Total & $\%$ & $<30$ dan $>70$ & $46.78-57.43$ \\
4 & Kadar Air & $\%$ & & $25.05-37.47$ \\
5 & Derajat Pelulusan Air & $\mathrm{cm} \mathrm{jam}^{-1}$ & $<0.7$ dan $>8.0$ & $6.27-29.81$ \\
6 & C-Organik & $\%$ & & $0.48-2.19$ \\
\hline
\end{tabular}

Tabel 2. Parameter kualitas air berdasarkan PP N0.82 tahun 2001

\begin{tabular}{|c|c|c|c|c|c|}
\hline \multirow{2}{*}{ PARAMETER } & \multirow{2}{*}{ SATUAN } & \multicolumn{4}{|c|}{ KELAS } \\
\hline & & I & II & III & IV \\
\hline Suhu & ${ }^{\circ} \mathrm{C}$ & \multicolumn{4}{|c|}{ Deviasi 3 (sesuai keadaan lingkungan) } \\
\hline $\mathrm{Ph}$ & & $6-9$ & $6-9$ & $6-9$ & $5-9$ \\
\hline BOD & $\mathrm{mg} \mathrm{L}^{-1}$ & 2 & 3 & 6 & 12 \\
\hline COD & $\mathrm{mg} \mathrm{L}^{-1}$ & 10 & 25 & 50 & 100 \\
\hline Timbal & $\mathrm{mg} \mathrm{L}^{-1}$ & 0.03 & 0.03 & 0.03 & 1 \\
\hline Sedimen & $\mathrm{mg} \mathrm{L}^{-1}$ & 50 & 50 & 400 & 400 \\
\hline
\end{tabular}


Tabel 3. Klasifikasi nilai koefisien regim aliran

\begin{tabular}{lcc}
\hline No & Nilai KRA & Kelas \\
\hline 1. & $\leq 20$ & Sangar rendah \\
2. & $20<\mathrm{KRA} \leq 50$ & Rendah \\
3. & $50<\mathrm{KRA} \leq 80$ & Sedang \\
4. & $80<\mathrm{KRA} \leq 110$ & Tinggi \\
5. & KRA $>110$ & Sangat Tinggi \\
\hline
\end{tabular}

Sumber: Peraturan Menteri Kehutanan Republik Indonesia No: 61 tahun 2014

\section{Koefisien Aliran Tahunan (KAT)}

KAT merupakan perbandingan perbandingan antara direct run off (tebal aliran tahunan yang sudah dikurangi base flow) dengan tebal hujan tahunan ( $\mathrm{mm}$ ) pada suatu DAS untuk mengetahui persentase curah hujan yang menjadi aliran (run off) (Tabel 4). Cara perhitungan Koefisien Regim Aliran dapat dihitung dengan rumus sebagai berikut:

$$
\text { Koefisien Aliran Tahunan }=\frac{\text { Direct run off } / D R O(\mathrm{~mm})}{\text { Curah hujan tahunan }(\mathrm{mm})}
$$

Tabel 4. Klasifikasi nilai Koefisien Aliran Tahunan

\begin{tabular}{ccc}
\hline No & Nilai KAT & Kelas \\
\hline 1 & 0.2 & Sangat Rendah \\
2 & $0.2-0.3$ & Rendah \\
3 & $0.3-0.4$ & Sedang \\
4 & $0.4-0.5$ & Tinggi \\
5 & $>0.5$ & Sangat Tinggi \\
\hline
\end{tabular}

Sumber: Peraturan Menteri Kehutanan Republik Indonesia No: 61 tahun 2014

\section{HASIL DAN PEMBAHASAN}

\section{Kerusakan Tanah}

Berdasarkan hasil pengamatan di lapangan kerusakan tanah yang berada di DAS Pedindang paling parah terjadi di lahan tambang. Areal lahan bekas penambangan didominasi oleh lahan berpasir, yang kondisi lahan berpasir ini sulit digunakan untuk lahan pertanian. Hasil pengamatan lapangan ditampilkan pada Tabel 5.

Berdasarkan penilaian ambang batas kerusakan tanah menurut PP No 150 tahun 2000 maka parameter permeabilitas dan kerapatan isi tanah pada penggunan lahan tambang di semua kemiringan lereng melebihi ambang batas kerusakan tanah. Penggunaan lahan pertanian lahan kering di kemiringan 8-15\% menunjukkan nilai permeabilitas yang masih dalam ambang batas, sedangkan pada kemiringan lereng lainnya melewati ambang batas kerusakan tanah. Parameter kerapatan isi di lahan kemiringan 25-40\% melewati ambang batas kerusakan tanah. Lahan semak belukar pada parameter permeabilitas tanah di kemirngan 8-15\% masih berada dalam ambang batas kerusakan tanah, sedangkan pada parameter kerapatan isi di lahan semak belukar melewati ambang batas.

Parameter kadar air, permeabilitas, kerapatan isi di semua penggunaan lahan tambang dan semak belukar pada semua kemiringan lereng melewati ambang batas kerusakan tanah. Parameter kadar air, permeabilitas, kerapatan isi, dan porositas tanah di penggunaan lahan pertanian pada kemiringan lereng $25-40 \%$ melewati nilai ambang batas kerusakan tanah

Fraksi partikel pasir berukuran besar ( 2 sampai 0.05 $\mathrm{mm}$ ) sehingga ukuran pori pasir relatif lebih besar. Ukuran pori yang besar menyebabkan air mudah lolos dan tidak terikat oleh fraksi pasir. Semakin tinggi persentase pasir dalam tanah semakin banyak ruang-ruang pori diantara partikel-partikel tanah semakin dapat memperlancar gerakan udara dan air (Hakim et al., 1986). Kerapatan tanah pada bagian atas lahan lahan tambang dipengaruhi oleh aktifitas manusia berupa pengupasan tanah, pencucian, penimbunan dan pemadatan materi tanah dengan alat-alat berat tambang. Selama pemadatan, partikel-partikel tanah bergerak menjadi lebih rapat, sehingga dapat meningkatkan bobot isi, pori mikro, dan konduktivitas termal serta menurunkan pori makro, konduktivitas hidrolik dan laju pengambilan air (Ghildyal, 1978).

Tabel 5. Pengukuran sifat fisik tanah berupa kadar air, permeabilitas, kerapatan isi, dan porositas tanah di DAS Pedindang

\begin{tabular}{|c|c|c|c|c|c|}
\hline $\begin{array}{l}\text { Kemiringan } \\
\text { Lahan }\end{array}$ & $\begin{array}{c}\text { Penggunaan } \\
\text { Lahan }\end{array}$ & $\begin{array}{c}\text { Kadar Air } \\
(\%)\end{array}$ & $\begin{array}{l}\text { Permeabilitas } \\
\left(\mathrm{cm} \mathrm{jam}^{-1}\right)\end{array}$ & $\begin{array}{l}\text { Kerapatan isi } \\
\left(\mathrm{g} \mathrm{cm}^{-3}\right)\end{array}$ & $\begin{array}{c}\text { Porositas } \\
(\%)\end{array}$ \\
\hline \multirow[t]{4}{*}{$0-8 \%$} & Eks Tambang & 17.38 & 73.62 & 1.51 & 43.17 \\
\hline & Hutan & 28.88 & 27.22 & 1.23 & 53.58 \\
\hline & Pertanian Lahan Kering & 31.15 & 20.58 & 1.27 & 56.82 \\
\hline & Semak Belukar & - & - & - & - \\
\hline \multirow[t]{4}{*}{$8-15 \%$} & Tambang & 11.97 & 67.68 & 1.53 & 41.58 \\
\hline & Hutan & 25.05 & 6.27 & 1.30 & 47.56 \\
\hline & Pertanian Lahan Kering & 30.79 & 7.60 & 1.31 & 50.48 \\
\hline & Semak Belukar & 23.29 & 3.63 & 1.38 & 45.74 \\
\hline \multirow[t]{4}{*}{$15-25 \%$} & Tambang & 20.57 & 60.96 & 1.44 & 45.02 \\
\hline & Hutan & 28.96 & 9.32 & 1.29 & 51.03 \\
\hline & Pertanian Lahan Kering & 20.77 & 24.93 & 1.32 & 48.00 \\
\hline & Semak Belukar & - & - & - & - \\
\hline \multirow[t]{4}{*}{$25-40 \%$} & Hutan & 29.42 & 29.81 & 1.37 & 46.78 \\
\hline & Tambang & - & - & - & - \\
\hline & Pertanian Lahan Kering & 19.04 & 30.57 & 1.43 & 41.34 \\
\hline & Semak Belukar & - & - & - & - \\
\hline \multirow[t]{4}{*}{$>40 \%$} & Tambang & - & - & - & - \\
\hline & Hutan & 37.47 & 25.85 & 1.13 & 57.43 \\
\hline & Pertanian Lahan Kering & 27.62 & 22.85 & 1.32 & 54.88 \\
\hline & Semak Belukar & - & - & - & - \\
\hline
\end{tabular}


Tabel 6. Pengukuran kelas tekstur dan bahan organik pada empat penggunaan lahan dan lima kemiringan di DAS Pedindang

\begin{tabular}{|c|c|c|c|c|c|}
\hline \multirow{2}{*}{ Kemiringan } & \multirow{2}{*}{ Penggunaan Lahan } & \multicolumn{3}{|c|}{ Tekstur } & \multirow{2}{*}{ C-Organik (\%) } \\
\hline & & Pasir (\%) & Klei $(\%)$ & Debu $(\%)$ & \\
\hline \multirow{4}{*}{$0-8 \%$} & Tambang & 87.91 & 9.91 & 30.65 & 0.46 \\
\hline & Hutan & 69.54 & 16.08 & 14.39 & 2.19 \\
\hline & Pertanian Lahan Kering & 75.65 & 15.22 & 9.61 & 1.92 \\
\hline & Semak Belukar & - & - & - & - \\
\hline \multirow{4}{*}{$8-15 \%$} & Tambang & 89.33 & 3.52 & 7.15 & 0.08 \\
\hline & Hutan & 75.62 & 18.90 & 5.49 & 1.69 \\
\hline & Pertanian Lahan Kering & 79.27 & 16.34 & 4.40 & 1.56 \\
\hline & Semak Belukar & 56.76 & 37.00 & 6.25 & 1.12 \\
\hline \multirow{4}{*}{$15-25 \%$} & Tambang & 88.36 & 10.56 & 1.08 & 1.07 \\
\hline & Hutan & 76.07 & 20.21 & 4.23 & 1.90 \\
\hline & Pertanian Lahan Kering & 79.98 & 17.24 & 2.78 & 1.51 \\
\hline & Semak Belukar & - & - & - & - \\
\hline \multirow{4}{*}{$25-40 \%$} & Tambang & - & - & - & - \\
\hline & Hutan & 67.97 & 11.14 & 20.90 & 1.18 \\
\hline & Pertanian Lahan Kering & 80.34 & 12.66 & 7.00 & 1.93 \\
\hline & Semak Belukar & - & - & - & - \\
\hline \multirow{4}{*}{$>40 \%$} & Tambang & - & - & - & - \\
\hline & Hutan & 3.34 & 2.3 & 94.36 & 0.48 \\
\hline & Pertanian Lahan Kering & 61.74 & 30.3 & 7.95 & 1.99 \\
\hline & Semak Belukar & - & - & - & - \\
\hline
\end{tabular}

Penilaian menggunakan PP No 150 tahun 2000. Penggunaan lahan tambang didominasi oleh fraksi pasir yang melewati ambang batas kerusakan tanah, karena jumlah fraksi pasir melebihi ambang batas pasir kuarsitik >80. Lahan tambang yang berada di DAS Pedindang di dominasi oleh tanah berpasir akibat pencucian tanah. Menurut Ang dan Ho dalam Inonu (2011) lahan tambang timah didominasi oleh tailing timah, hampir $80 \%$ dari tailing timah ini berupa tailing pasir (sand tailing) dan sisanya meruapakan tailing lumpur (slime tailing). Berdasarakan jenisnya, tanah yang berada di DAS Pedindang berjenis Ultisols berbahan granit yang kaya akan mineral kuarsa mempunyai tekstur kasar seperti liat berpasir. Parameter C-Organik menunjukan nilai terendah C-Organik terdapat pada penggunaan lahan tambang dikemiringan $0-8 \%$ dan $8-15 \%$ menunjukkan nilai COrganik kategori rendah, sedangkan pada kemiringan lereng $15-25 \%$ menunjukan nilai C-Organik dalam kategori rendah.

\section{Kualitas Air DAS Pedindang}

Hulu DAS Pedindang merupakan sumber air yang digunakan masyarakat sekitar DAS untuk kehidupan sehari-seharinya. Hulu dan hilir DAS mempunyai nilai parameter yang berbeda karena pengaruh kondisi dan lokasi DAS dekat dengan kegiatan masyarakat. Analisa sampel air kualitas air ditampilkan pada Tabel 7.

Nilai terendah $\mathrm{pH}$ terdapat pada sampel Pedindang 4 yaitu 4.5 yang masuk kriteria $\mathrm{pH}$ sangat masam, hal ini terjadi karena pada stasiun Pedindang 4 banyak sekali aktifitas tambang inkonvensional masyarakat, sedangkan $\mathrm{pH}$ tertinggi terdapat pada sampel Pedindang 6 yaitu 6.2 hampir mendekati $\mathrm{pH}$ netral, dimana pada posisi sampel Pedindang 6 tidak terdapat tambang masyarakat, hanya terdapat perkebunan masyarakat berupa lada dan sawit. Angka parameter suhu paling rendah terdapat pada sampel Pedindang 5 dan 7 yaitu $23{ }^{\circ} \mathrm{C}$ masih dalam keadaan suhu sejuk, dimana pada stasiun Pedindang 5 dan 7 keadaan lingkungan disekitar hulu masih terlindungi hutan yang berada disekitar, sedangkan nilai suhu tertinggi terdapat pada sampel Pedindang 4 yaitu 30 ${ }^{\circ} \mathrm{C}$ yang termasuk suhu yang sedikit hangat, dimana pada stasiun Pedindang 4 keadaan saluran sungai tidak terlindungi tutupan lahan dan terpapar langsung oleh sinar matahari. Hubungan antara suhu air dan kandungan oksigen yang terlarut didalamnya mempunyai hubungan korelasi negatif, yaang menyebabkan kenaikan suhu air menurunkan tingkat solubilitas oksigen dan menurunkan kemampuan oraganisme dalam memanfaatkan oksigen yang tersedia, sehingga proses biologi dapat berjalan semestinya (Asdak, 2014).

Parameter COD dan BOD terendah terdapat pada sampel Pedindang 5 yaitu $68 \mathrm{mg} \mathrm{l}^{-1}$ untuk COD dan $22 \mathrm{mg}$ $\mathrm{I}^{-1}$ untuk BOD, karena posisi keadaan stasiun pengambilan sampel Pedindang 5 masih terlindungi oleh tutupan hutan yang masih rapat, dan tidak ada aktifitas tambang yang berada disekitarnya. Parameter BOD dan COD yang tertinggi terdapat pada sampel Pedindang 4 yaitu, $138 \mathrm{mg}$ $\mathrm{l}^{-1}$ pada BOD dan $55 \mathrm{mg} \mathrm{l}^{-1}$ pada parameter COD, hal ini dikarenakan karena disekitar stasiun pengambilan sampel Pedidndang 4 banyak sekali aktifitas tambang masyarakat sehingga mempengaruhi nilai BOD dan COD yang berada. Menurut Hindriani (2013), pada pengukuran BOD dan COD tidak selalu meningkat dari setiap titik dan dari setiap musimnya, karena di setiap titik dan di setiap musimnya dapat terjadi pemasukan buangan organik ke sungai dengan konsentrasi dan debit tertentu yang dapat menyebabkan penurunan atau peningkatan BOD dan COD sungai. 
Tabel 7. Perbandingan suhu, BOD, COD, dan $\mathrm{pH}$ di 7 lokasi pengambilan sampel.

\begin{tabular}{|c|c|c|c|c|c|c|c|}
\hline $\begin{array}{c}\mathrm{No} / \\
\text { Kode Lokasi }\end{array}$ & Kondisi & $\mathrm{pH}$ & $\begin{array}{l}\text { Suhu } \\
\left({ }^{0} \mathrm{C}\right)\end{array}$ & $\begin{array}{c}\text { COD } \\
\left(\mathrm{mg} \mathrm{l}^{-1}\right)\end{array}$ & $\begin{array}{c}\text { BOD } \\
\left(\mathrm{mg} \mathrm{l}^{-1}\right)\end{array}$ & $\begin{array}{c}\mathrm{Pb} \\
\left(\mathrm{mg} \mathrm{l}^{-1}\right)\end{array}$ & Sedimen $\left(\mathrm{mg} \mathrm{l}^{-1}\right)$ \\
\hline Pedindang 1 & Hulu Mangkol tambang & 5.9 & 25 & 82 & 39 & $<0.030$ & 0.031 \\
\hline Pedindang 2 & Hulu Mangkol pertanian & 5.2 & 25 & 71 & 26 & $<0.030$ & 0.022 \\
\hline Pedindang 3 & Pertengahan hulu Mangkol tambang & 4.8 & 25 & 80 & 33 & $<0.030$ & 0.003 \\
\hline Pedindang 4 & Hilir Mangkol lahan tambang & 4.5 & 30 & 138 & 55 & 0.859 & 1.330 \\
\hline Pedindang 5 & Hulu Mesu tengah hutan terlindungi & 5.5 & 23 & 68 & 22 & $<0.030$ & 0.005 \\
\hline Pedindang 6 & Hulu Mesu lahan pertanian & 6.2 & 25 & 75 & 26 & $<0.030$ & 0.002 \\
\hline Pedindang 7 & Hulu Mangkol hutan terlindungi & 5.5 & 23 & 73 & 29 & $<0.030$ & 0.005 \\
\hline
\end{tabular}

Tabel 8. Parameter kualitas air berdasarkan PP No. 82 tahun 2001

\begin{tabular}{|c|c|c|c|c|c|}
\hline \multirow{2}{*}{ Parameter } & \multirow{2}{*}{ Satuan } & \multicolumn{4}{|c|}{ Kelas } \\
\hline & & $\mathrm{I}$ & II & III & IV \\
\hline Suhu & ${ }^{0} \mathrm{C}$ & \multicolumn{4}{|c|}{ Deviasi 3 (sesuai keadaan lingkungan) } \\
\hline $\mathrm{Ph}$ & & $6-9$ & $6-9$ & $6-9$ & $5-9$ \\
\hline BOD & $\mathrm{mg} \mathrm{L}^{-1}$ & 2 & 3 & 6 & 12 \\
\hline COD & $\mathrm{mg} \mathrm{L}^{-1}$ & 10 & 25 & 50 & 100 \\
\hline Timbal & $\mathrm{mg} \mathrm{L}^{-1}$ & 0.03 & 0.03 & 0.03 & 1 \\
\hline Sedimen & $\mathrm{mg} \mathrm{L}^{-1}$ & 50 & 50 & 400 & 400 \\
\hline
\end{tabular}

Tabel 9. Nilai koefisien regim aliran $\left(\mathrm{m}^{3}\right.$ detik $\left.^{-1}\right)$ DAS Pedindang selama tahun 2011-2015

\begin{tabular}{cccccc}
\hline Tahun & Debit Rata-rata & Qmax & Qmin & KRA & Kelas \\
\hline 2011 & 10.49 & 20.70 & 3.97 & 5.21 & Sangat rendah \\
2012 & 7.18 & 31.70 & 2.06 & 15.39 & Sangat rendah \\
2013 & 4.41 & 18.96 & 1.43 & 13.24 & Sangat rendah \\
2014 & 7.81 & 19.96 & 2.99 & 6.34 & Sangat rendah \\
2015 & 3.15 & 23.60 & 0.07 & 318.25 & Sangat tinggi \\
\hline
\end{tabular}

Parameter nilai timbal tertinggi terdapat pada sampel Pedindang 4 sedangkan 6 sampel lainnya masih berada dalam standar Baku Mutu Air yaitu <0.030. Nilai sedimen dan kekeruhan paling rendah terdapat pada sampel Pedindang 6 yaitu 0.002 sedangkan nilai sedimen dan kekeruhan paling tinggi terdapat pada sampel Pedindang 4 yaitu $1.330 \mathrm{mg} \mathrm{l}^{-1}$. Kandungan logam berat pB dalam air dipengaruhi oleh total logam berat dalam tanah dan pengaruhi emisi dari sekitar sungai tersebut. Menurut Alooway (1995) kandungan logam berat bersumber dari bahan induk tanah, deposisi atmosflirik, penumpukan sampah-sampah organik dan pencemar anorganik. Pengaruh dari emisi yang berasal dari sekitar lokasi juga menentukan kandungan timbal. Nilai partikel timbal diudara yang terbawa angin dan air hujan yang jatuh lagi ke bumi dan mengalir di aliran permukaan dan mengendap di aliran sungai (Gidding, 1973)

\section{Koefisien Regim Aliran dan Koefisien Aliran Tahunan}

Total debit aliran yang mengalir dalam DAS Pedindang menunjukkan debit rata-rata tertinggi terjadi pada tahun 2011 yaitu sebesar $10.49 \mathrm{~m}^{3}$ detik $^{-1}$. Sementara untuk nilai debit rata-rata terendah terjadi pada tahun 2015 yaitu sebesar $0.07 \mathrm{~m}^{3}$ detik $^{-1}$. Perhitungan metode KRA didapatkan nilai terendah KRA terjadi pada tahun 2011 yaitu $5.21 \mathrm{~m}^{3}$ detik $^{-1}$ masuk dalam klasifikasi DAS sangat baik, dan nilai KRA sangat tinggi terjadi pada tahun 2015 dengan nilai KRA 318.25 yang masuk dalam klasifikasi DAS sangat buruk.

Penyebab utama terjadinya lonjakan nilai KRA yang sangat tinggi pada tahun 2015 lebih disebabkan oleh terjadinya perubahan penggunaan lahan dan anomali cuaca yang ekstrim. Penurunan tutupan lahan karena aktifitas manusia meyebabkan menurunnya fungsi DAS Pedindang, sehingga saat terjadi anomali cuaca yang ekstrim berupa musim kemarau panjang pada Bulan Juni sampai Bulan Oktober tahun 2015, nilai Qmin yang dihasilkan sangat rendah yaitu $0.07 \mathrm{~m}^{3}$ detik $^{-1}$. Hal ini berbanding terbalik dengan nilai Qmax yang tinggi pada tahun 2015 yaitu $23.60 \mathrm{~m}^{3}$ detik $^{-1}$, sehingga mengakibatkan tingginya nilai KRA pada tahun 2015. Menurut Rodriguez et al. (2010) dalam Nugroho (2015) mendukung pernyataan dari peneliti sebelumnya yang menyatakan bahwa perubahan tata guna lahan dan penutupan lahan berdampak pada naiknya puncak banjir (Qmax) dan menurunkan aliran minimal (Qmin). Menurut Haryanto et al. (2017) adanya kesenjangan antara musim penghujan dan musim kemarau, kemudian pengaruh koefisien Infiltrasi dan koefisien Run Off mempengaruhi Total Direct Run Off dalam suatu area.

Perhitungan dari nilai Koefisien Aliran Tahunan yang terjadi di dalam DAS Pedindang selama rentang waktu lima tahun, dimulai dari tahun 2011 sampai tahun 2015 menunjukkan yang bervariatif setiap tahunnya. Jumlah curah hujan yang terjadi tahun 2011 sebesar 2,898.90 mm tahun ${ }^{-1}$, dengan nilai KAT adalah 0.42

Tabel 10. Nilai koefisien aliran tahunan DAS Pedindang selama tahun 2011-2015

\begin{tabular}{crrrl}
\hline Tahun & $\Sigma$ Aliran $(\mathrm{mm})$ & $\mathrm{P}(\mathrm{mm})$ & KAT & Klasifikasi \\
\hline 2011 & $1,208.47$ & $2,898.80$ & 0.42 & Tinggi \\
2012 & 715.69 & $2,017.50$ & 0.35 & Sedang \\
2013 & 613.81 & $2,844.60$ & 0.22 & Rendah \\
2014 & 601.68 & $1,653.70$ & 0.36 & Sedang \\
2015 & 344.76 & $1,519.70$ & 0.23 & Rendah \\
\hline Keterangan: & Q TRO: Debit & Total Run & Off; P: & Presipitasi; Q \\
& DRO: Debit Direct Run Off; BF: & Base Flow; C: \\
& Koefisien & & & \\
& & &
\end{tabular}

DAS Pedindang memiliki nilai KAT yang bervariasi dari tahun 2011 sampai tahun 2015. Tahun 2011 DAS Pedindang mengalami peningkatan nilai KAT paling besar dari 4 tahun lainnya yang masuk kategori tinggi. 
Penurunan nilai Koefisien Aliran Tahunan menjadi kategori sedang terjadi pada tahun 2012 dan 2014, sedangkan tahun 2013 dan 2014 terjadi penurunan nilai C Aliran Koefisien Tahunan menjadi kategori rendah. Fluktuasi nilai KAT lebih disebabkan oleh kapasitas infiltrasi, intensitas curah hujan dan distribusinya. Perubahan penggunaan lahan dan/atau penutupan lahan di suatu DAS juga dapat mempengaruhi dan mengubah proses hidrologi seperti infiltrasi, resapan air tanah, aliran dasar dan limpasan (Rachman, 2018)

\section{SIMPULAN}

Kualitas air yang berada di hilir DAS Pedindang mengalami penurunan mutu air yang berasal dari aktifitas penambangan yang mempengaruhi baku mutu air yang digunakan untuk aktifitas masyarakat setempat. Fluktuasi koefisien Regim Aliran selama 5 tahun menunjukkan debit aliran terjadi akibat perubahan penggunaan lahan yang mempengaruhi hidrologis DAS dan anomali perubahan curah hujan. Koefisien Aliran Tahunan selama 5 tahun yang menunjukkan adanya penurunan nilai KAT dari tahun 2012 sampai 2015. Nilai KAT dipengaruhi oleh Curah hujan dan kapasitas infiltrasi yang mempengaruhi aliran permukaan.

\section{DAFTAR PUSTAKA}

Alloway, B.J. 1995. Heavy Metals in Soils. Chapman \& Hall. London

Asdak, C. 2014. Hidrologi dan Pengelolaan Daerah Aliran Sungai. Gadjah Mada University Press. Yogyakarta

[BPDASHL] Balai Pengelolaan Daerah Aliran Sungai dan Hutan Lindung Baturusa

Cerucuk. 2012. Rencana Teknik Lapangan Rehabilitasi Lahan dan Konservasi Tanah (RTL - RLKT) DAS Baturusa_Cerucuk. BPDAS. Bangka Belitung

[DLH] Dinas Lingkungan Hidup Daerah Provinsi Bangka Belitung. 2016. Buku Laporan Status Lingkungan Hidup Daerah Provinsi Kepulauan Bangka Belitung. Provinsi Bangka Belitung. Bangka

Ghildyal, B.P. 1978. Effects of compactions and puddling on soil physical properties and rice growth in soil and rice. Soil and Rice. P.317-336.
Gidding, J.C. 1973. Chemistry, Mans and Environmental Changes: An Integrated Approach. Canfield. New York

Haryanto, E.T., Hendrawan, E. Sukiyah dan B. Joy. 2017. Analisis Hasil Air ("Water Yield") Berdasarkan Debit Aliran Sungai, DTA Citarik Bagian Hulu, Desa Tanjungwangi, Kecamatan Cicalengka, Kabupaten Bandung, Jawa Barat: Bulletin of Scientific Contribution, Vol 15, Nomor 1, April 2017: $17-26$

Hakim, N., M.Y. Nyakpa, A.M. Lubis, S.G. Nugroho, M.A. Diha, G.B. Hong dan H.H. S. 1986. DasarDasar Ilmu Tanah. Universitas Lampung.

Hindriani, H. 2013. Kajian Peningkatan Kualitas Air Sungai Ciujung Berdasarkan Parameter Senyawa Aox (Adsorbable Organic Halides) Dengan Model Wasp (Water Quality Analysis Simulation Program) Dan Model Dinamis. [Disertasi]. Sekolah Pascasarjana IPB. Bogor

Inonu, I., D. Budianta, M. Umar, Yakup, A.Y.A. Wiralaga. 2011. Respon klon karet terhadap frekuensi penyiraman di media tailing pasir pasca penambangan timah. J. Agron., 39(2): 131-136.

Nugroho, H.Y.S.H. 2015. Analisis Debit Aliran DAS Mikro dan Potensi Pemanfaatannya. Jurnal Penelitian Kehutanan Wallacea, 4(1): 23 - 34

Rachman L.M. 2018. Potensi, Peran Dan Kontribusi Perguruan Tinggi Dalam Restorasi Sungai. Prosiding Fakultas Geografi Universitas Muhamadiyah. (Belum Terbit)

Republik Indonesia. 2000. Peraturan Pemerintah No 150 Tahun 2000 tentang Pengendalian Kerusakan Tanah untuk Produksi Biomassa. Sekertariat Negara Republik Indonesia. Jakarta

Republik Indonesia. 2001. Peraturan Pemerintah No 82 Tahun 2001 tentang Pengelolaan Kualitas Air dan Pengendalian Pencemaran Air. Sekertariat Negara Republik Indonesia. Jakarta

Republik Indonesia. 2014. Peraturan Menteri Kehutanan No 61 Tahun 2014 tentang Monitoring Dan Evaluasi Pengelolaan Daerah Aliran Sungai. Sekertariat Negara Republik Indonesia. Jakarta 